\title{
Thought on Complementation of Legal Education and Ideological \& Political Education
}

\author{
Hongliang Hao \\ Ningxia Medical University, Yinchuan Ningxia, 750004, China
}

Key words: legal education, Ideological and political education, Complementation.

\begin{abstract}
. legal education and ideological \& political education are important constituent parts of ideological education, and they have differences and connections. Ideological and political education involves legal education more or less. We can also say legal education is an essential education content in ideological and political education. Both have their own defects and limitations, and they have certain complementary effect. It is necessary to deeply analyze and explore the complementary relationship between the two, strive to combine legal education and ideological \& political education in practical education process and make up for respective limitations, which is very important for promoting the development of ideological and political education, and improving education pertinence and effectiveness.
\end{abstract}

\section{Introduction}

With raid economic development and social progress, the field of ideological and political education also becomes increasingly wide. Besides, the objects of education also become more and more complex. In order to adapt to increasingly complex education demand, the mode and method of ideological and political education are also continuously updated and improved, and they basically adapt to requirements of ideological and political education in the new period. However, ideological and political education also has its limitations, and it cannot replace legal education.. in the process of ideological and political education, legal education is required. In the process of legal education, ideological and political education is also needed. Both have respective limitations and features. Only when they are combined can they make up for respective defects and make education effect reach the ideal level[1]. Thus, in the specific ideological education process, it is required to scientifically apply legal education and ideological \& political education according to different teaching form, properly adjust them, make them cooperate with each other and give full play to their complementation so as to reach the expected education effect and purpose and improve people's quality.

\section{Complementation between ideological \& political education and legal education}

Although legal education and ideological \& political education exist independently in the specific education process, they have close correlation. Regardless of education content and education function, they have strong complementary relationship, which is reflected in the following aspects:

\section{Complementary relationship in terms of education content}

Ideological \& political education and legal education have different emphases. Law which is formulated by legal subjects at all levels and supported by coercive force of the state is used to standardize people's behavioral norms in daily life. Legal education educates people to observe law and discipline so as to standardize people's life order and guarantee social healthy development and stable operation. Meanwhile, legal education makes people own better development in the healthy 
and orderly living environment, establish correct life view and value and achieve life value. Ideological and political education mostly educates others from the perspectives of reason and human nature according to people's living essence, makes people learn to understand and respect others through receiving ideological and political education and improve people's moral accomplishment inwardly so as to facilitate better development, improve basic quality of all citizens and promote all-round and sound development of the society[2]. In current education environment, the main aim of ideological and political education is to cultivate the citizens with dream, culture, morality and discipline so as to adapt to the needs of national construction in the new period and become the main force in national construction. Wherein, “discipline” includes generalized compliance with law and discipline, which is consistent with the essence of legal education. The education perspective and education mode of both are different. Legal education stresses it more specifically and practically, while ideological and political education is relatively general.

Although education method and content of both are different, their education essence is same, and the education contents of both also have certain complementary relationship. Ideological and political education pays attention to improvement and development of comprehensive quality, and educates people to respect others in daily life so as to achieve improvement of personal value and ensure all-round and sound development of the society. The purpose of legal education also has the same features, but the content of legal education is more specific and explicit than that of ideological and political education. Legal education tells people red lines in daily life, what they can do and what they cannot do. its education essence is also to standardize people's behaviors in daily life so as to achieve life value and safeguard stable operation and development of the society. Ideological and political education achieves overall improvement of people's quality through various educational means such as politics, economy, culture and science. The law regards compulsory laws and regulations as the main tool, makes sure citizens abide by laws and maintains social life order through coercive force of the state. The means used by the two are different, but the education purpose is indeed correlated. Legal education well complements insufficient coerciveness in ideological and political education and makes the standards of observing law and discipline more specific. For the ideology and morality part which is not involved in legal education, ideological and political education well complements it, and the two complements each other.

\section{Complementary relationship in terms of education method}

Legal education and ideological \& political education have certain complementary relationship in the aspect of education method. The purpose of both legal education and ideological \& political education is to standardize and educate people inwardly, let people know behavior legality in advance and then make a decision[3]. In accordance with the view of ideology and politics, consciousness is decided by materials, and the behavior derives from ideology in brain and is decided by human ideology. We know that ideology is mainly influenced by external material and economic conditions. So, both ideological \& political education and legal education influence human thought through external material and economic condition stimulus so that the educatees form good ideology, make standard and legal behaviors. The education modes of both are different. The education method of ideological and political education is relatively mild. It mainly guides people to standardize their behaviors from the perspective of moral theory so as to achieve harmonious and sound development of the society. Legal education has certain coerciveness, standardizes and restrains people's behaviors through national peremptory norms. Once one violates the law, he will suffer strict legal sanction. Legal education will generate intimidation effect to certain extent and let people observe law and discipline due to fear of laws.

Both also differ in education level. The level of legal education is relatively low. Both guidance comment and prediction comment are at the level of standardizing people's behaviors. As long as people do not do anything against the law, they do not break the law. The education process does not involve people's thought. The level of ideological and political education is relatively high. It no just involves behaviors, but also involves ideological level. It pays certain education role for people's 
thought, morality, behavior and character, starts from the influence on people's thinking and makes people make certain judgment before acting. Thus, both are opposite in the education process, but form favorable complementation and bring better education effect.

\section{Both have respective limitations, but can form complementary relationship if they are combined}

Due to the lack of corresponding coerciveness, ideological and political education needs legal education. Ideological and political education has its limitations. For example, there are certain quantities of norm systems and standards of behaviors, but these norms or standards belong to moral aspect, and people need to abide by them by their consciousness. Its essence is to utilize people's moral level, ideological quality and consciousness to standard their behaviors. The education function of morality provides certain selection space. It is good to abide by morality, but it does not matter if one violates morality. The worst situation is that he will be condemned by the public. The effect is much lighter than compulsory legal sanction. Thus, to make ideological and political education reach the ideal effect, legal education must offer certain assistance. With the guarantee of national coerciveness, the good effect of ideological and political education may be ensured. Since morality does not own coerciveness, when people act, they not just need to consider moral constraints subjectively, but also need to take into account of coercive effect of law objectively, because once one breaks the law, he will suffer severe legal sanction. Such subjective and objective effects make people more conform to norms when they act.

On the other hand, due to the limitations of law, it is impossible to standardize all aspects in life. Thus, law is not almighty. Law is a tool used by the ruling class to standardize the behaviors of the ruled class. It belongs to superstructure. Thus, the law as the superstructure is based on economic development. The formulation of law must adapt to economic development. But, economic society develops continuously, and it impossibly standards still all the time. The cost of formulating laws is high, and frequent formulation and alteration of laws will make laws lose original authority, so the law is always in the hysteretic state, relative to economic development ${ }^{[4]}$. When economic continuously develops and the society makes progress continuously, hysteretic nature of laws will start to stand out. At this time, the education function of law weakens. Thus, ideological and political education is required to supplement legal education. In this way, stable social relations and be maintained and social sound development can be ensured.

\section{Effective strategies to achieve complementation between legal education and ideological \& political education in practice}

\section{To lay emphasis on legal education in ideological and political education}

Ideological and political education has advantages in multiple aspects. It can achieve the purpose of standardizing behaviors inwardly, but it is still necessary to pay attention to legal education. Since ideological and political education lacks certain coerciveness, legal education must be applied to reach the purpose of ideological education. Many democratic systems are still not sound in China, and it is required to legalize and standardize some democratic systems so as to reach the purpose of standardizing behaviors. In addition, with rapid economic development, people's living standards are improving year after year and many open thoughts emerge continuously. If there is short of certain coerciveness and normalization, the effect of ideological and political education will inevitably weaken. Besides, ideological and political education is essential for any era. So, corresponding laws and regulations should be improved to standardize ideological and political education.

Moreover, if legal education is implemented before ideological and political education, a good effect will be reached. Since Third Plenary Session of the $11^{\text {th }}$ Central Committee of the Chinese Communist Party was convoked, legal education popularization has been carried out vigorously across the country. Students receive legal education from the period of primary school so that they form the good habit of observing law and discipline. If ideological and political education is 
implemented on this basis, education effect will improve greatly. This is because people have had the awareness of observing law and discipline, their behaviors have been standardized to a large extent. So, it is much easier to standardize their ideology. Therefore, legal education should be implemented first in the process of ideological and political education. Then, ideological and political education is carried out to improve people's moral level. This will get twofold results with the half effort.

\section{To intensify awareness of ideological and political education in legal education process}

The main purpose of legal education is to standardize people's behaviors. Such education has certain legal coerciveness. In the process of legal education, it is required to pay attention to the purpose of ideological and political education and enhance people's understanding and grasp of legislative spirit. For any era, legislative spirit is consistent with the overall objective of ideological and political education. Legal education emphasizes national coerciveness, while ideological and political education is relatively mild ${ }^{[5]}$. The purpose of law making is to conform to era development, standardize people's behaviors with progressive and developmental norms. Thus, the law which conforms to the era plays a positive role in promoting the development of the society and economy. The law reflects the thought and will of ruling class. The purpose of legal education is to let the ruled class to act according to the will of ruling class so as to facilitate harmonious development of the society. Hence, it is required to enhance the awareness of ideological and political education, and try to reach the purpose of standard and education ideologically. In the process of legal education, it is required to pay attention to understanding of laws, regulations and legislation idea, stress national coerciveness and severe sanction of laws, attach importance to the education of legal spirit, and standardize moral level and external behavior level like ideological and political education so as to reach the expected education aim and effect.

\section{Conclusions}

The rapid development of economy and society needs favorable moral environment. Good moral environment cannot be separated from the combined action of ideological \& political education and legal education. In the specific education process, legal education with the support of national coercive force should be applied to standardize people's external behaviors and achieve the expected effect of legal education. In the field that the law cannot reach, ideological and political education should be applied to standardize people's internal behaviors from ideological and moral level and let people's moral level improve so as to achieve the purpose of ideological and political education. Ideological \& political education and legal education should cooperate with each other. They can neither be mutually independent nor replace each other completely. The two should be combined to give play to the supplementary effect and reach the education purpose from external and internal level.

\section{References}

[1] Liu Qing, Thought on Implementing Holistic View of Ideological and Political Education in Teaching Fundamentals of Law, Reform \& Opening, 2013(8):178.

[2] Ling Ping, Thought on Legal Education - from the Perspective of Legal Education in Ideological and Political Education of Middle Schools, Reference For Middle School Education, 2015(27):55-55.

[3] Li Huailiang, Exploration on Effect of Legal Education in Ideological and Political Education of University Students, Legality Vision, 2015(4):304-304.

[4] Miu Wenwu, Discussion on Problems of Legal Education in the Course of Ideological and Moral Cultivation and Legal Basis, Cai Zhi, 2013(1):14-14. 
[5] Li Zijun, Exploration On Reform of Legal Education in the Course of Ideological and Moral Cultivation and Legal Basis, Qiu Zhi Dao Kan, 2015(5):83-83. 